\title{
Matthew Lawson Koma Skoru
}

๑) Serdar Özdemir',®Abdullah Algın'

'Department of Emergency Medicine, University of Health Sciences Umraniye Training and Research Hospital, Istanbul, Turkey

\section{Matthew Lawson Koma Skoru}

Sayın editör,

Kritik hastanın tespiti ve tedavinin yönetilmesinde pek çok klinik ve laboratuvar parametrelerini de içeren skorlama sistemleri geliştirilmiştir. Bu skorlama sistemlerinden baziları Glasgow Koma Skalası, Acute Physiology and Chronic Health Evaluation II, Rapid Acute Physiology Score, Rapid Emergency Medicine Score olarak sayılabilir. Günlük pratikte sıklıkla kullanılan skorlama sistemleri acil serviste kritik hastanın tespiti için kullanılabileceği gibi yoğun bakım ünitelerinde hastanın tedaviye yanıtını değerlendirme amaciyla da kullanılabilmektedir.

Acil servis ve yoğun bakım pratiğinde kritik hasta yönetiminde bilinç takibi vital parametrelerle birlikte önemli bir klinik belirteçtir. Bilinç durumunun değerlendirmesinde yaygın olarak kullanılan skorlama sistemi Glasgow Koma Skalasıdır. Bunun yanı sira Matthew ve Lawson tarafindan 1966 yılında önerilen Matthew Lawson Koma Skoru özellikle zehirlenme hastalarında kullanılmaktadır. Matthew ve Lawson 1966 yılında yaptıkları araştırmada skorlama sistemini tanımladılar ve barbiturat intoksikasyonu hastalarında kullanılabileceğini önerdiler'. Starmark ve Heath 1988 yılında intihar amaçlı kendini zehirleyen 26 hastanın verilerini incelediği çalışmada Matthew Lawson Koma Skorunun kullanılabileceğini önerdiler ${ }^{2}$. Hultén ve arkadaşları da 1992 yılında yaptıkları çalışmada Matthew Lawson Koma Skorunun trisiklik antidepresan intoksikasyonunda da güçlü bir prediktör olduğunu gösterdiler ${ }^{3}$. Staniszewska ve Bujalska-Zadrożny ise 2016 yılında yayınlanan Varşova'da yaptıkları çalışmada akut valproik asit zehirlenmeli 26 hastanın verilerini analiz ettiler ${ }^{4}$. Staniszewska ve Bujalska-Zadrożny yaptıkları araştırmada serum valproik asit düzeyinin araştırılan parametreler ile arasında ilişki olmadığını ortaya koyarken Matthew Lawson Koma Skorunun hastanede kalış süresi ile ilişsili olduğunu raporladılar'.
Bilinç düzeyi, Matthew Lawson Koma Skoruna göre 0 ile 4 arasında derecelendirilir ve seviyeler roma rakamları ile gösterilir. Grade 0 , tamamen bilinçli, uyanık hali ifade eder. Grade I, uykulu ancak sözlü komuta yanıt verme hali ifade eder. Grade II, bilinçsiz hastayı ifade eder ancak hasta minimal ağrılı uyaranlara yanıt verir ve refleksler bozulmamıştır. Grade III, bilinçsiz hastayı ifade eder ve hasta maksimal ağrilı uyaranlara yanıt verir, yüzeysel reflekslerin yoktur ve derin refleksler hafif alınabilir. Grade IV, ağrılı uyaranlara yanıt vermeyen bilinçsiz hastayı ifade eder, korneal, laringeal, faringeal dahil tüm reflekslerin kaybı söz konusudur. Grade III ve IV şiddetli zehirlenme olarak kabul edilir ${ }^{1}$.

Matthew Lawson Koma Skorunun az sayıda örneklemler ile yapılan çalışmalarda özellikle santral sinir sistemini etkileyen ilaç zehirlenmelerinde kullanılabileceği önerilmektedir. Bu skorun geliştirilmesi ve ülkemiz ve dünya literatürüne katkı sağlamak amacıyla zehirlenme alanında geniş örneklemler ile yapılacak çalışmalara ihtiyaç vardır.

\section{Anahtar Kelimeler: koma,toksikoloji,skor}

\section{References}

1. Matthew $H$, Lawson $A A H$. Acute barbiturate poisoning, a review of two years experience. Q J Med 1966; 35: 539-552

2. Starmark JE, Heath $A$. Severity grading in self-poisoning. Hum Toxicol. 1988 Nov;7(6):551-5. doi: 10.1177/096032718800700606. PMID: 3229764.

3. Hultén BA, Adams R, Askenasi $R$, et al. Predicting severity of tricyclic antidepressant overdose. Journal of toxicology. Clinical Toxicology. $1992 ; 30(2): 161-170$. DOI: 10.3109/15563659209038628.

4. Staniszewska A, Bujalska-Zadro ny M. Acute Valproic Acid Intoxication: An Attempt at Estimating the Correlation Between Serum Level and Clinical Manifestations. In: Kalinin $\checkmark$ editör. Epileptology- The Modern State of Science 2016: 225-235. 